\title{
Expression of Galphal 4 in sweet-transducing taste cells of the posterior tongue
}

\author{
Marco Tizzano $^{\dagger 1,2}$, Gennady Dvoryanchikov ${ }^{\dagger 3}$, Jennell K Barrows ${ }^{1,2}$, \\ Soochong Kim ${ }^{4}$, Nirupa Chaudhari ${ }^{3,5}$ and Thomas E Finger*1
}

\begin{abstract}
Address: ${ }^{1}$ Rocky Mountain Taste \& Smell Center, Univ. Colorado Denver Sch. Medicine, Aurora CO 80045 USA, ${ }^{2}$ Dept. Cell \& Devel. Biology, Univ. Colorado Denver Sch. Medicine, Aurora CO 80045 USA, ${ }^{3}$ Department of Physiology and Biophysics, University of Miami Miller School of Medicine, Miami, FL 33136 USA, 'Department of Physiology, Temple University Medical School, 3420 N Broad St, Philadelphia, PA 19140 USA and 5 Program in Neurosciences, University of Miami Miller School of Medicine, Miami, FL 33136 USA

Email: Marco Tizzano - marco.tizzano@uchsc.edu; Gennady Dvoryanchikov - GDvoryantchikov1@med.miami.edu; Jennell K Barrows - jennell.barrows@uchsc.edu; Soochong Kim - skim0026@temple.edu; Nirupa Chaudhari - NChaudhari@med.miami.edu; Thomas E Finger* - tom.finger@uchsc.edu

* Corresponding author †Equal contributors

Published: 13 November 2008

BMC Neuroscience 2008, 9:110 doi:10.1186/147|-2202-9-110

Received: 2 August 2008

Accepted: 13 November 2008

This article is available from: http://www.biomedcentral.com/I47I-2202/9/II0

(C) 2008 Tizzano et al; licensee BioMed Central Ltd.

This is an Open Access article distributed under the terms of the Creative Commons Attribution License (http://creativecommons.org/licenses/by/2.0), which permits unrestricted use, distribution, and reproduction in any medium, provided the original work is properly cited.
\end{abstract}

\begin{abstract}
Background: "Type II"/Receptor cells express G protein-coupled receptors (GPCRs) for sweet, umami (TIRs and mGluRs) or bitter (T2Rs), as well as the proteins for downstream signalling cascades. Transduction downstream of TIRs and T2Rs relies on G-protein and PLC $\beta 2$-mediated release of stored $\mathrm{Ca}^{2+}$. Whereas Gagus (gustducin) couples to the T2R (bitter) receptors, which G $\alpha$-subunit couples to the sweet (TIR2 + TIR3) receptor is presently not known. We utilized RTPCR, immunocytochemistry and single-cell gene expression profiling to examine the expression of the $\mathrm{G} \alpha \mathrm{q}$ family $(\mathrm{q}, \mathrm{II}, \mathrm{I4})$ in mouse taste buds.

Results: By RT-PCR, Gal4 is expressed strongly and in a taste selective manner in posterior (vallate and foliate), but not anterior (fungiform and palate) taste fields. $G \alpha q$ and $G \alpha$ II, although detectable, are not expressed in a taste-selective fashion. Further, expression of Ga/4 mRNA is limited to Type II/Receptor cells in taste buds. Immunocytochemistry on vallate papillae using a broad $\mathrm{G} \alpha \mathrm{q}$ family antiserum reveals specific staining only in Type II taste cells (i.e. those expressing TrpM5 and PLC 32 ). This staining persists in G $\alpha$ q knockout mice and immunostaining with a G $\alpha$ IIspecific antiserum shows no immunoreactivity in taste buds. Taken together, these data show that $\mathrm{G} \alpha / 4$ is the dominant $\mathrm{G} \alpha \mathrm{q}$ family member detected. Immunoreactivity for Gal4 strongly correlates with expression of TIR3, the taste receptor subunit present in taste cells responsive to either umami or sweet. Single cell gene expression profiling confirms a tight correlation between the expression of G 14 and both TIR2 and TIR3, the receptor combination that forms sweet taste receptors.
\end{abstract}

Conclusion: $\mathrm{G \alpha} / 4$ is co-expressed with the sweet taste receptor in posterior tongue, although not in anterior tongue. Thus, sweet taste transduction may rely on different downstream transduction elements in posterior and anterior taste fields. 


\section{Background}

Taste buds, the end-organs for gustation, detect and respond to a variety of macronutrient and aversive compounds to generate taste perception. Compounds that evoke bitter taste bind to one or more G protein coupled receptors (GPCRs) of the T2R family of taste receptors [13]. Amino acids and compounds that elicit umami taste bind to a variety of GPCRs including metabotropic glutamate receptors, mGluR4 and mGluR1, and the heterodimeric taste receptor, T1R1+T1R3 [4-7]. Sugars and a variety of other sweeteners bind to the heterodimeric receptor, T1R2+T1R3[5,8]. Most of these various taste GPCRs appear to all couple to a common transduction pathway that includes the heterotrimeric $G$ protein subunits, G 33 and G $\gamma 13$, a phospholipase C, PLC $\beta 2$, and a transient receptor potential ion channel, TrpM5 [9-14].

In spite of the detailed exploration of the G $\beta \gamma$-triggered signaling, much less is understood of which Ga subunits couple to various taste GPCRs, and which downstream signaling pathways they recruit. Taste buds are reported to express a number of different subunits including Gagus

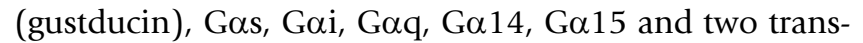
ducin isoforms, Gat1 and Gat2 [15-18]. Apart from Gagus, it remains unknown which of these are expressed in the same cells as taste GPCRs and might be candidate signaling partners. In vitro, the sweet taste receptor, T1R2+T1R3, couples via Gai to cAMP modulation[19]. Although Gai subunits are expressed in taste buds[20], it is unclear which receptors activate them in situ. Biochemical and physiological studies have suggested that bitter taste transduction includes the involvement of Gagus, although the exact mechanism of such involvement remained unclear[13,21,22]. While Gagus-knockout mice are quite insensitive to bitter tastants, they are also somewhat compromised in their detection of sweet tastants[23]. Gustducin is co-expressed with the T1R2+T1R3 sweet receptor in the palate [24] and fungiform papillae[25] but not in the posterior gustatory fields. Furthermore, the direct functional role of Gagus in sweet detection has not been demonstrated. The Gagus, Gai and Gas subunits alter cAMP levels when activated, while members of the Gaq family trigger release of stored $\mathrm{Ca}^{2+}$. The primary cellular response triggered by tastants appears to be a $\mathrm{Ca}^{2+}$ signal. Although much of this signal is produced via the action of G $\beta \gamma$ subunits[9], the contribution of the Gaq family has not been examined in taste buds.

Mammalian taste buds are composed of up to 100 cells. Though most mature cells in taste buds have a generally fusiform shape, they can be distinguished into several distinct types based on their functional properties and the expression of diagnostic mRNA and protein markers. Based on ultrastructural and other criteria, cells in rodent taste buds are classified as "Type I", the glial-like or supporting cells, "Type II", the primary receptor cells, and "Type III", the cells that show specialized chemical synapses[26]. Type II cells are characterized by the ubiquitous expression of PLC $\beta 2$ and TrpM5 [20,27-29]. Subsets of Type II cells express either T2Rs or T1Rs[8], an observation that suggested the segregated detection of tastants of the sweet and bitter qualities. Subsequent functional studies have demonstrated the equivalence of cell types identified by expression patterns and cells with particular response profiles. For instance, cells that express NCAM and SNAP25 were shown to be those that display voltagegated calcium channels[29,30]. Cells that express TrpM5 or PLC $\beta 2$ are those that respond to bitter or sweet stimuli[29,31]. Here, we have used RT-PCR, immunocytochemistry and single-cell gene expression profiling to examine the expression of the Gaq family $(\alpha q, \alpha 11$, a14)[32] in mouse taste buds and establish which of these are co-expressed with T1R2 and T1R3, subunits that constitute the sweet taste GPCR. The pattern of expression suggests that Gagus is unlikely to be a signaling partner for T1R2+T1R3. Instead, the sweet receptor subunits consistently are co-expressed with G $\alpha 14$.

\section{Results \\ G $\alpha$ q family members are differentially expressed in different taste fields}

First, we used end-point RT-PCR to evaluate the expression of Gaq family subunits in taste buds to assess which members, if any, of the Gaq family (Gaq, Ga11 and Go14) are expressed in taste buds. We analyzed taste buds obtained from four different oral taste fields (vallate, foliate, fungiform and palate) as well as non-taste lingual and palatal epithelium.

As shown in Fig. 1A, Ga14 is strongly expressed in vallate and foliate taste buds, with somewhat lower expression in the palate. Under parallel conditions, expression of G $\alpha 14$ was negligible in the fungiform field. Gaq also was not detected in fungiform papillae, and its mRNA was seen in taste buds from vallate, foliate and palate. Finally, we observed that Go11 appeared to be expressed similarly in taste buds of all taste fields. Of these three G $\alpha$ subunits, $\mathrm{G} \alpha \mathrm{q}$ and $\mathrm{G} \alpha 11$ were detected in non-taste mRNA at roughly similar levels as in taste buds. In contrast, G $\alpha 14$ was expressed in a highly taste-selective manner. We also tested expression of the distantly related subunit, G $\alpha 15$. We detected RT-PCR product for G $\alpha 15$ prominently in the nontaste epithelium samples and very little in vallate taste bud samples (data not shown). Thus, we did not investigate this subunit further. The taste selective expression pattern and apparently high mRNA level of Ga14 suggested that it may be the principal Gaq family member playing a taste-specific role in murine taste buds. 


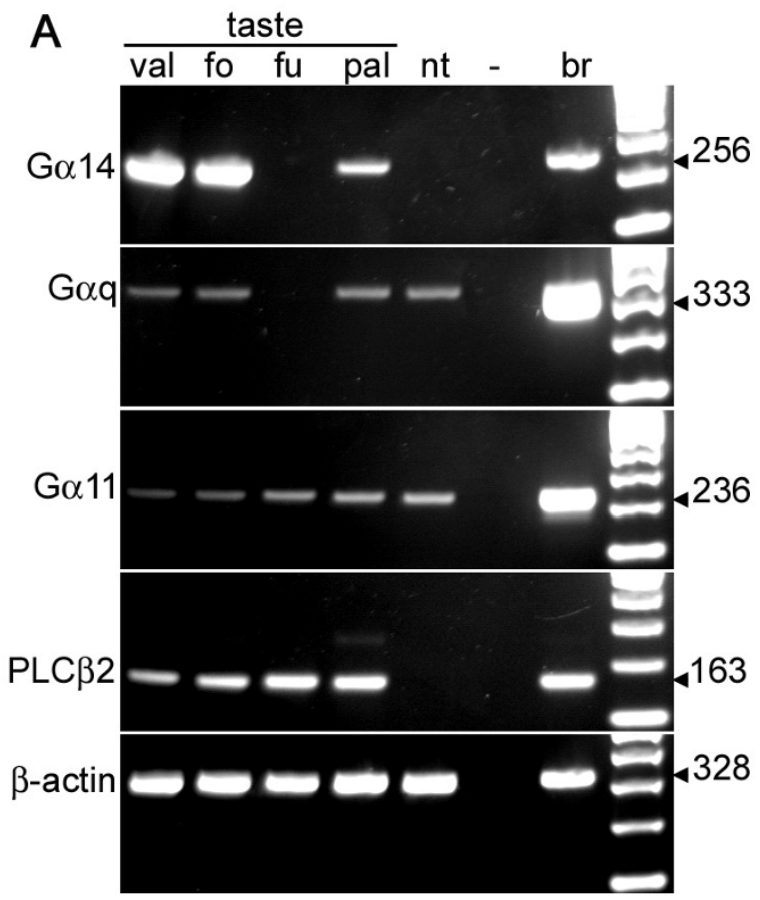

B

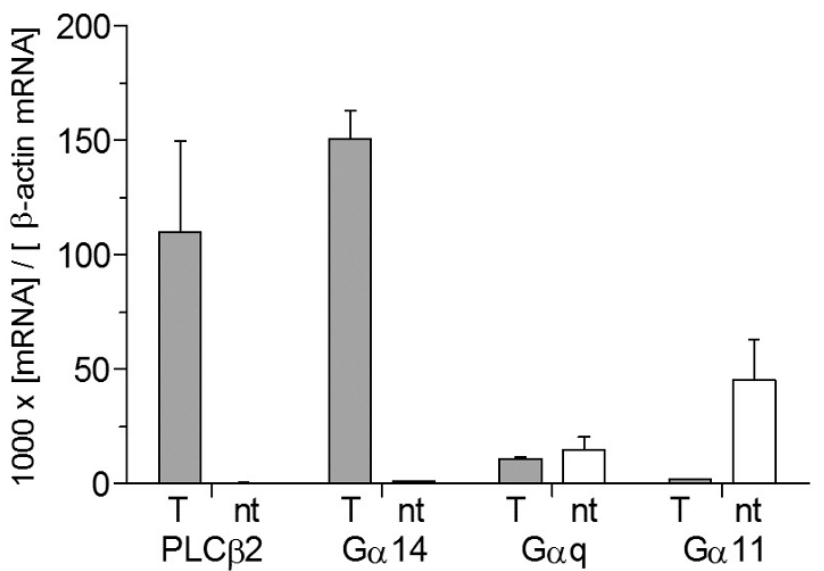

Figure I

Of $\mathbf{G} \alpha \mathbf{q}$ family members only $\mathbf{G} \alpha \mathbf{I} 4$ shows a taste bud-selective pattern. A. RT-PCR on isolated taste buds shows that $\mathrm{G} \alpha \mid 4, \mathrm{G} \alpha \mathrm{q}$ and $\mathrm{G} \alpha$ II are all expressed in vallate (val), foliate (fo) and palate (pal). Fungiform (fu) taste buds express $\mathrm{G} \alpha$ II but $G \alpha / 4$ and $G \propto q$ are not readily detected. Of these $G \alpha$ subunits, only $G \alpha / 4$ is expressed in a taste-selective fashion (i.e. is absent from non-taste lingual epithelium [nt]). Brain (br) cDNA and water in place of cDNA (-) served as positive and negative controls run in parallel for all PCRs. Predicted sizes of products (in basepairs) are to the right. All templates were also analyzed for PLC 32 , a gene expressed in all taste buds and for $\beta$-actin, expressed in all cells. B. Quantitative RT-PCR shows that only $\mathrm{G \alpha} / 4$ is prominently expressed in a taste-selective manner. mRNA from three samples of CV taste buds ( $T$ = gray bars) and of nontaste lingual epithelium ( $\mathrm{nt}=$ white bars) were analyzed for expression of $\mathrm{G} \alpha \mathrm{q}, \mathrm{G} \alpha \mid \mathrm{I}$ and $\mathrm{G} \alpha \mid 4$. The same samples were also analyzed in parallel for $\beta$-actin as a normalization control and PLC $\beta 2$ as a taste-selective marker.

To test this, we undertook quantitative RT-PCR experiments to compare expression levels of the Gaq family members in taste buds (Fig. 1B). The concentration of Go14 mRNA in vallate taste buds was comparable to that of PLCB2 mRNA. Neither mRNA was expressed in nontaste epithelium. In contrast, Gaq mRNA was found at similar concentration in CV taste buds and in nontaste epithelium while $\mathrm{G} \alpha 11$ was at much higher concentration in nontaste epithelium than in taste epithelium. Thus, neither $\mathrm{G} \alpha 11$ or $\mathrm{G} \alpha \mathrm{q}$ are expressed in a taste-selective manner. Further, the mRNAs for Gaq and Ga11 are expressed at 14- and 80-fold lower concentrations respectively than Ga14 mRNA. These data support our interpretation from end-point RT-PCR, that the only G $\alpha$ subunit of this family that is likely to have a taste-selective role is Ga14.

Taste buds contain two cell types that have been functionally defined to date, Type II/Receptor cells and Type III/

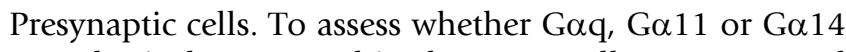
are selectively expressed in these two cell types, we used PLC $32-G F P$ and GAD-GFP transgenic mice that respectively illuminate Type II and III taste cells $[33,34]$. Individual GFP-labeled cells from each strain were harvested to produce 3 pools, each of 10 cells, representing Type II and Type III cells respectively. We examined expression of the G $\alpha$ subunits by RT-PCR on amplified RNA from these 6 pools (Fig. 2). Ga14 expression was limited to Type II cells and was detected in each of the three pools. In contrast, G $\alpha \mathrm{q}$ expression was less prominent, and was found in Type II, Type III and non-taste epithelial cells, consistent with the qRT-PCR data of Fig. 1B. Ga11 was only sporadically detected in the pools of identified taste cells, consistent with the low level seen in qRT-PCR with whole vallate taste buds. The absence of Ga11 in the isolated non-taste cells may reflect the heterogeneity of the nontaste epithelium, with some regions expressing G $\alpha 11$ and others not. In summary, RT-PCR analyses suggested that 


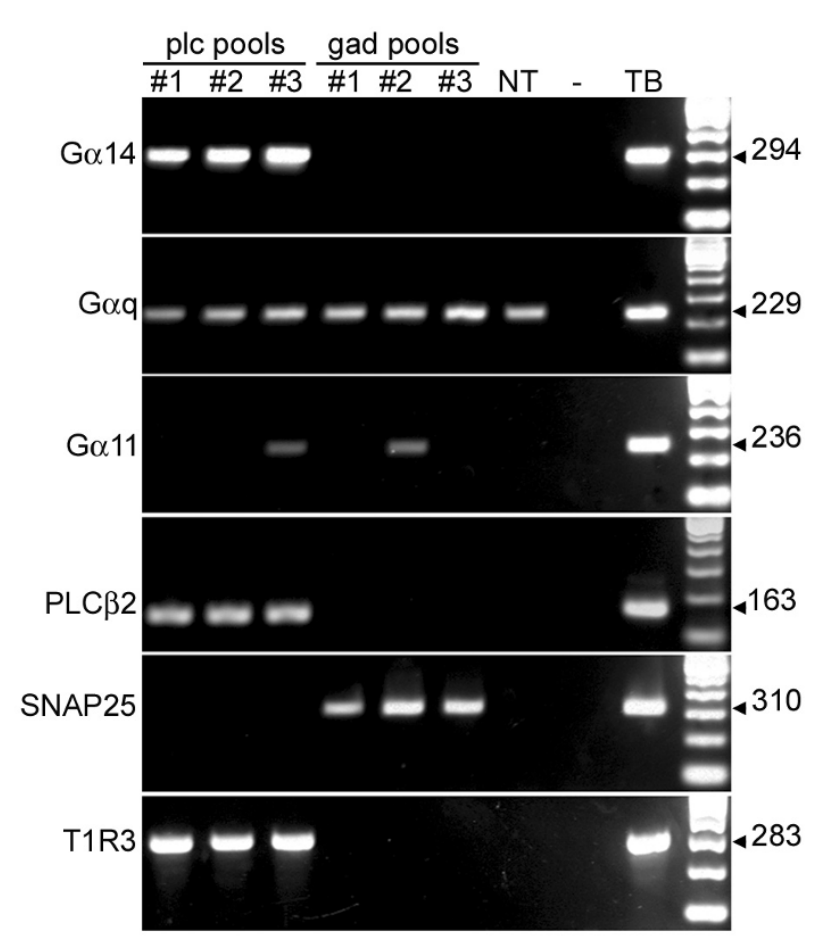

Figure 2

Gol4 is expressed only in Type II/Receptor cells. Three pools (\#I, 2, 3), each containing ten individual GFP(+) taste cells were collected from PLC $\beta 2$-GFP mice (plc pools) or from GAD-GFP mice (gad pools). Amplified mRNAs from these pools represent Type II and Type III cells respectively and were analyzed by RT-PCR. RNA from a cluster of nontaste epithelial cells (NT) and a taste bud (TB) were amplified and analyzed in parallel. A negative control (-) reaction was run with no cDNA. RT-PCR for PLC $\beta 2$ (Type II cells), TIR3 (Type II cells) and SNAP25 (Type III cells) [29] confirmed that the pools were not cross-contaminated with cells of the opposing type.

Ga14, expressed only in taste buds, and only in Type II/ Receptor cells within taste buds, was a reasonable candidate for coupling to a taste GPCR.

\section{Immunoreactivity to G $\alpha$ q-family in G $\alpha$ gus-negative Type II cells}

Next, we used an antiserum that recognizes Gaq, G $\alpha 11$ and $\mathrm{G} \alpha 14$ to perform fluorescent immunocytochemistry on cryosections of taste epithelia. The Gq/11/14 antibody reacted with a subset of taste cells in posterior (vallate and foliate) but not anterior (fungiform and palate) oral taste fields (Fig. 3). Immunoreactive cells in each case were elongate and spindle-shaped, as is typical for mature taste cells. Immunoreactivity appeared to be membrane-associated, largely encircling the taste cell profiles of immunoreactive cells. Relative to the signal in the vallate papilla, immunoreactivity to Gq/11/14 antibody occurred only rarely in cells of taste buds in the soft palate, and was essentially absent in taste buds of the fungiform papillae and pharynx (Fig. 3).

$\mathbf{G} \alpha \mathbf{q}$-family-immunoreactivity is not due to $\mathbf{G} \alpha \mathbf{q}$ nor $\mathbf{G} \alpha \mathbf{I}$ To assess whether the Gaq-family immunoreactivity was attributable to Gaq, we examined immunoreactivity with the same Gq/11/14 antibody in Gaq-KO mice. In vallate taste buds, staining with anti-Gq/11/14 was essentially no different in Gaq-KO mice compared to WT controls (Fig. 4A, A'). Staining with anti-Gagus antibody also shows no difference in the Gaq-KO compared to WT animals (Fig. $\left.4 \mathrm{~B}, \mathrm{~B}^{\prime}\right)$ indicating that the G $\alpha \mathrm{q}-\mathrm{KO}$ did not disrupt expression of other taste-related G-proteins. The robust staining by the Gq/11/14 antibody in Gaq-KO mice indicates that the bulk of the staining observed with Gq/11/14 antibody

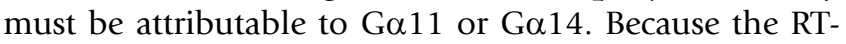
PCR data (see Figs. 1 \&2) showed that Go11 is expressed at very low levels, the combined analyses suggest that Ga14 is the principal Gaq family subunit in Type II (Receptor) cells.

To further test whether G $\alpha 11$ is present in taste buds, we utilized an antiserum directed against the N-terminal region of $\mathrm{G} \alpha 11$ which shares no sequence similarity to the

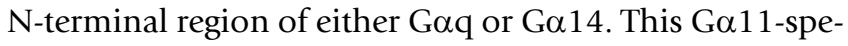
cific antiserum does not stain taste buds (Fig. 4C-C') although it does stain the cerebellar molecular layer (Fig. $4 \mathrm{E})$ in which Ga11 is detectable by immunocytochemistry[35]. These results essentially rule out Ga11 as the source of the taste bud immunoreactivity for the Gq/11/ 14 antibody. Since this Gq/11/14 antibody exhibits staining in Gaq knockout mice, we conclude that the staining is attributable to neither Gaq nor Ga11 leaving only Ga14 as the possible source of the immunoreactivity. These results are entirely consistent with our RT-PCR data (above) showing that Ga14 mRNA is the predominant Gaq family member isoform expressed in a taste-specific manner.

\section{G $\alpha$ q-family-immunoreactivity is in Type II Taste (Receptor) Cells}

Taste buds (TBs) comprise at least three different types of mature cells, so we utilized type-specific markers to test whether Gaq-family expression correlates with a specific cell type. Type II (receptor) cells express the GPCR taste receptors (T1Rs and T2Rs in different cells), TrpM5 and PLC $\beta 2$ [20,27-29]. Thus, we performed the first set of immunocytochemistry using tissues from TrpM5-GFP mice in which all GFP labeled taste cells express the TrpM5 protein[28]. In vallate taste buds, PLC $\beta 2$ antibody stained over $92 \%$ (25 of 27 cells) of TrpM5-GFP-labeled cells, confirming the identification of Type II cells with these markers. Further, in vallate taste buds, immunoreactivity to PGP9.5 antibody, which stains mostly Type III 


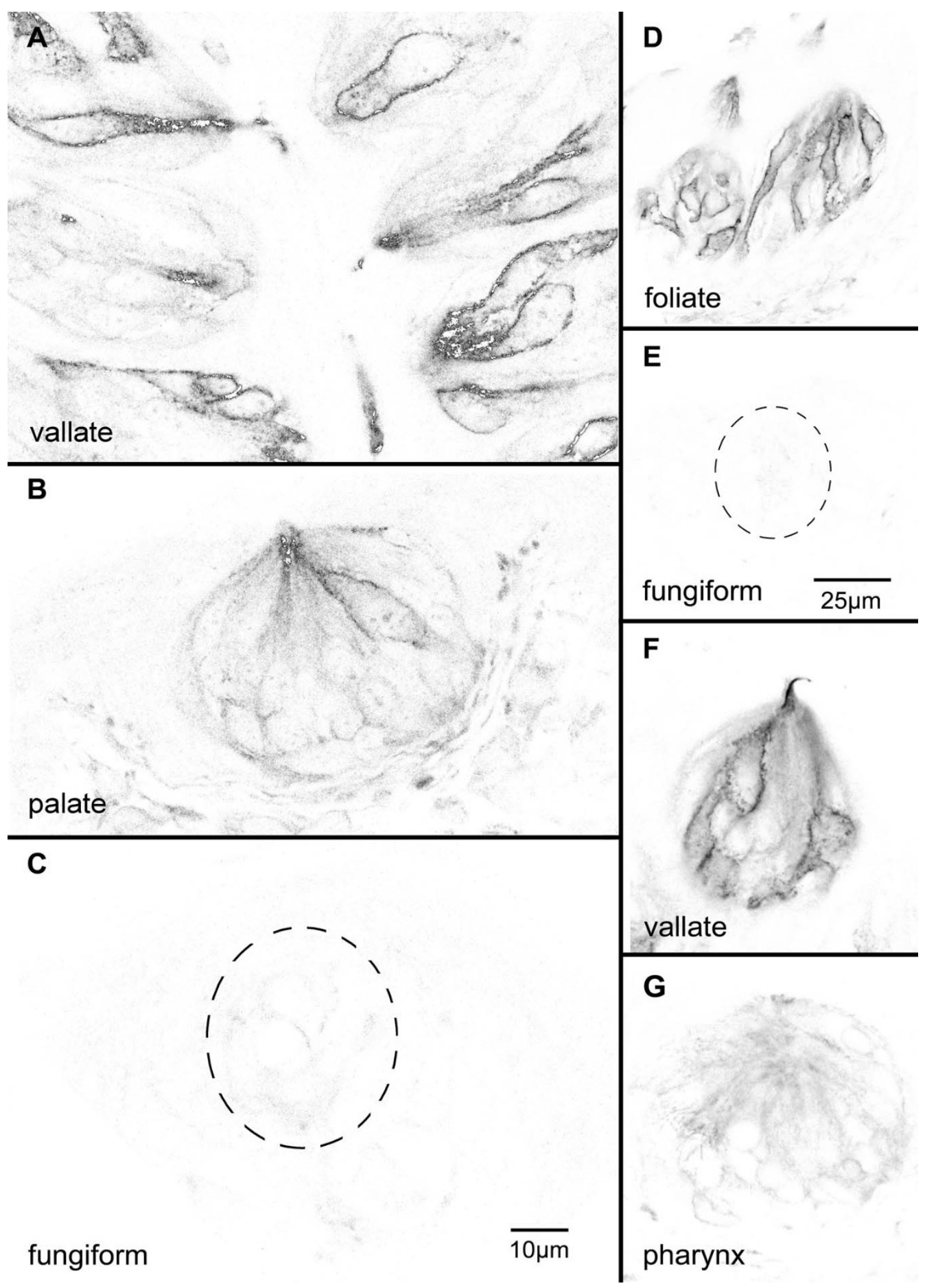

\section{Figure 3}

G $\alpha$ q-family immunoreactivity in different taste fields. Inverted grayscale images of single confocal image plane of immunofluorescence showing $\mathrm{G} \alpha \mathrm{q} / \mathrm{I} / \mathrm{l}$ 4-immunoreactivity in different taste fields. Acquisition and display parameters are matched to permit comparison of fluorescence intensity between image sets (A-C), (D-E) and (F-G). The heavy staining is largely membrane-associated and outlines the entire cell. Vallate (A \& F) and foliate field (D) taste buds each contain several Gaq/I I/I4-immunoreactive taste cells. Rare immunoreactive taste cells occur in palatal taste buds (B) but essentially no Gq/ I I/ I 4immunoreactivity is detected in fungiform field taste buds (C \& E). Similarly, pharyngeal taste buds exhibit little or no specific immunofluorescence. Scale bar equals $10 \mu \mathrm{m}$ for panels A-C and $25 \mu \mathrm{m}$ in D-G. 

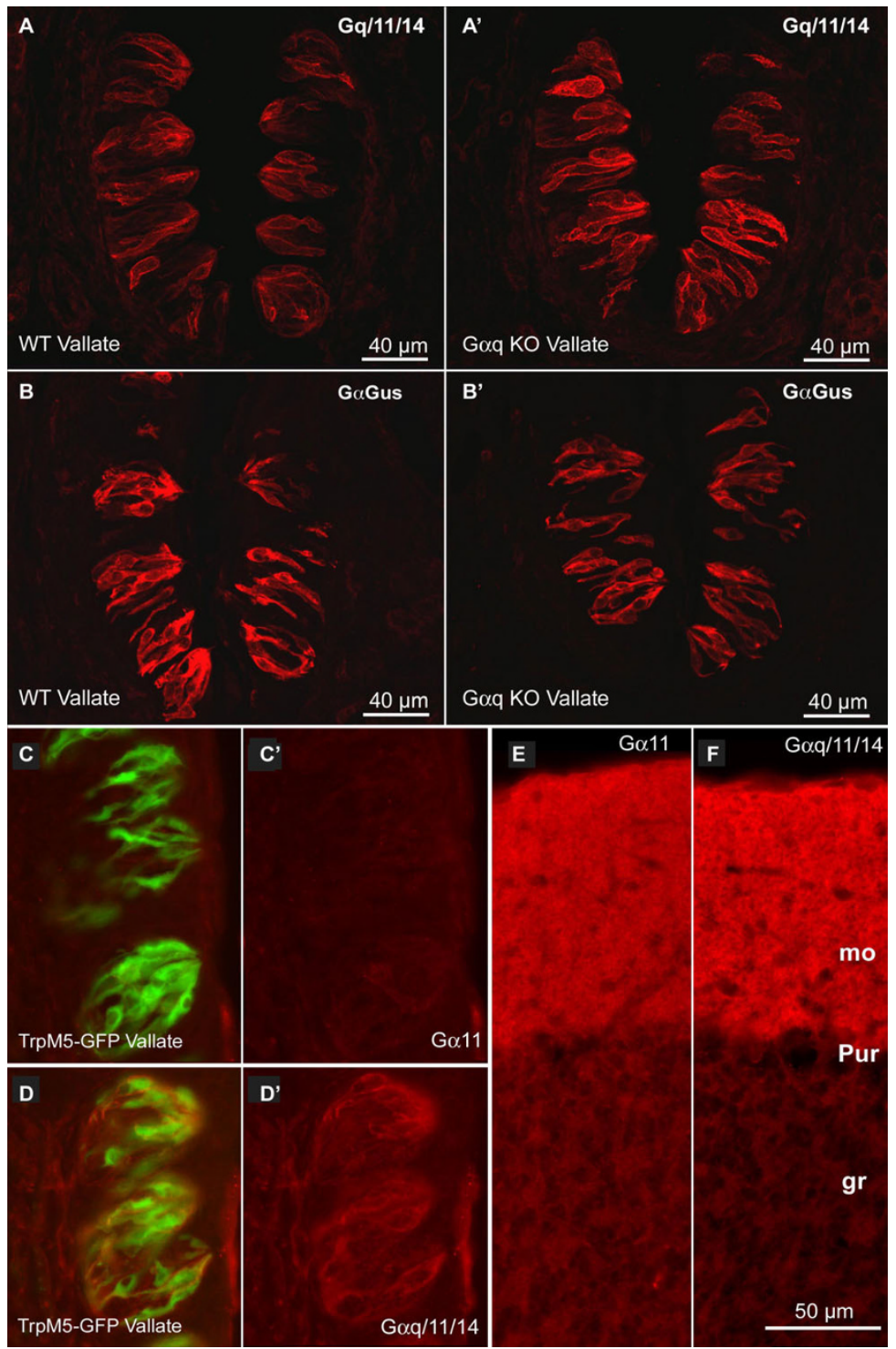

\section{Figure 4}

G $\alpha$ I 4 subunit expression in vallate papilla. Using Gaq-null mice and Gal I-specific anitserum, we show that the immunoreactivity in taste buds revealed by $\mathrm{Gq} / \mathrm{I} / / / 4$ antiserum must be due to $\mathrm{G \alpha} / 4$. (A) $\mathrm{Gq} / \mathrm{I} / / \mathrm{I} 4$ immunoreactivity in vallate papilla of (A) WT and (A') Gaq null mice. The continued immunoreactivity for Gq// I//4 in Gaq-null mice demonstrates that mem-

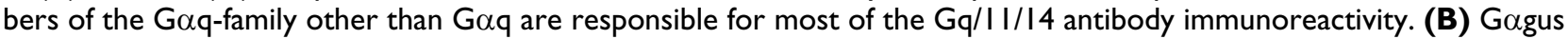
immunoreactivity in (B) WT and (B') Gaq null mice. Continued immunoreactivity for Gagus shows that other Ga expression is not altered in the Gaq null animals. Scale bars $=40 \mu \mathrm{M}$ for A-D. C-F: Micrographs of immunostaining of TrpM5-GFP mice with an antiserum specific for $\mathrm{G} \alpha \mathrm{II}\left(\mathrm{C}, \mathrm{C}^{\prime}, \mathrm{E}\right)$ or the broad $\mathrm{Gq}$ class antiserum (Gq/I I/I4) which reacts with $\mathrm{G} \alpha \mathrm{q}, \mathrm{G} \alpha \mathrm{II}$ and Gal4 (D, D', F). C, C': Section through taste buds of the vallate papilla stained with Gal I-specific antiserum (red). C. shows the combined image of TrpM5-GFP (green) and Gall (red); C' shows only the red channel of this same image. No specific Gal I staining is evident. This exposure is matched to that of panel E. E. Gal I staining of the cerebellum showing evident immunoreactivity of the molecular layer corresponding to the demonstrated presence of Gall in Purkinje cell dendrites[35,56]. D, D': Sections through taste buds of the vallate papilla stained with $\mathrm{Gq} / \mathrm{I}$ I/I4 antiserum (red). D shows the combined image of TrpM5-GFP (green) and Gq/I I/I4 (red); D' shows only the red channel of this same image. Many taste cells in each taste bud show clear membrane-associated immunoreactivity similar to that shown in Fig. 3. F. Gq/I I/I4 staining of the cerebellum showing evident immunoreactivity of the molecular layer corresponding to the demonstrated presence of $\mathrm{G} \alpha \mathrm{II}$ in

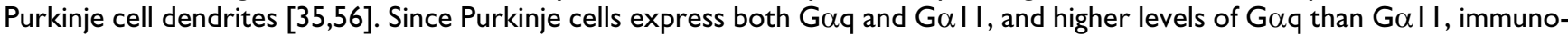

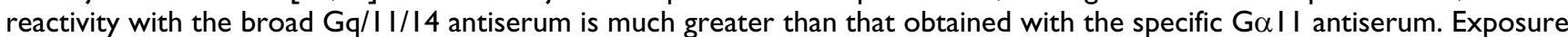
for this panel is $20 \%$ of that for panels $\mathbf{D}, \mathbf{D}^{\prime}$. Scale bar in $\mathbf{F}(50 \mu \mathrm{m})$ also applies to panels C, D \& E. 
cells [26]) was detectable only in a small percentage of TrpM5-GFP positive cells ( $\sim 4 \%$; 1 of 27 cells).

Next, we compared immunostaining for Gq/11/14 with staining for markers of Type II and Type III taste cells. In vallate and foliate taste buds of TrpM5-GFP mice, the Gq/ 11/14 antibody stained a subset of TrpM5-GFP cells (Fig. $5 A)$. Nearly all Gq/11/14 positive cells expressed TrpM5GFP (13/14), i.e. Gaq-family protein (presumed Ga14) is expressed only in Type II taste cells. We also immunostained the sections for Gagus and viewed them for fluorescence in three colors: GFP (green) for TrpM5, Alexa647 (pseudo-colored blue) for Gagus and Rhodamine RedX (red) for $\mathrm{Gq} / 11 / 14$. Most taste cells that were immunoreactive for Gq/11/14 lacked expression of Gagus (only 4 of 27 cells co-express these $\mathrm{G}$ protein alpha subunits; see Table 1). In contrast, antiserum to PGP9.5 (Type III cell marker) stained none of the Gq/11/14-positive cells (Fig. $5 \mathrm{~B})$. We conclude that Gaq-family immunoreactivity is not in Type III cells, but is common in the TrpM5-immunoreactive (Type II) receptor cell population.

\section{G $\alpha \mathbf{q}$-family immunoreactivity in TIR3-expressing cells}

Type II cells in taste buds express G protein coupled taste receptors for sweet, bitter or umami qualities. The taste receptors for sweet (T1R2 and T1R3) and for bitter (T2Rs) are expressed in separate subsets of Type II cells[1,8]. In taste membranes, bitter (T2R) taste receptors couple functionally to Gagus $[9,21,36,37]$. Yet to date, it is unclear which Ga subunits natively couple to the other class of taste receptors, the T1Rs. Because T1R3 appears to be an obligatory subunit in these dimeric receptors, we used T1R3-GFP transgenic mice, to ask whether the Gaq family subunits are co-expressed with T1R3. By double-immunostaining (Fig. 6), in vallate papillae we found that the $\mathrm{Gq} / 11 / 14$ antibody stained the majority of T1R3-GFP cells (85.7\%; 30 of 35 T1R3-GFP cells; see Table 1). In contrast, a smaller fraction of T1R3-GFP cells were strongly positive for Gagus ( 26.8\%; 11 of 41 T1R3-GFP cells; see Table 1) (Fig. 6). Thus Gagus expression does not correlate with T1R3 expression and therefore cannot be an obligatory partner in taste buds in vallate papillae.

\section{Single-cell RT-PCR shows co-expression of G $\alpha$ l4 with TIR2/TIR3}

We used transgenic PLC $\beta 2-G F P$ mice to isolate individual GFP-labeled (Type II/Receptor) cells and performed single cell-RT-PCR as an independent test of the expression pattern of Gaq-family subunits and sweet receptors (T1R2, T1R3). Because Ga11 expression was limited to a low concentration of mRNA (Fig. 1B) and only in a few cells (Fig. 2 ), we did not include it in this analysis. For this detailed analysis, we collected 21 individual PLC $\beta 2-G F P-e x p r e s s-$ ing (i.e. Type II/Receptor) cells and 2 PLC $\beta 2$-GFP-negative cells. As expected, TrpM5 was expressed in all 21 PLC $\beta 2-$
GFP cells, and was not detected in GFP-negative cells (Fig. $7)$. The taste receptors, T1R2 and T1R3 were detected in approximately half of GFP-positive cells (10 of 21 cells). All 10 of these T1R2+T1R3-expressing cells also expressed Ga14 (Table 1). In contrast, Gaq was detected in 50\%, and Gagus in only $40 \%$ of these T1R2+T1R3-expressing cells. In summary, Go14 is always found in presumptive sweet-sensing Type II/Receptor cells. Additionally, G $\alpha 14$ was not detected in the absence of T1R3. Thus, we propose that G $\alpha 14$ may be the principal G $\alpha$ subunit coupled to the sweet receptors.

\section{Discussion}

Using the complementary techniques of immunocytochemistry and gene expression profiling via single-cell RTPCR, we have explored the pattern of expression of the Gaq family of heterotrimeric $G$ protein subunits. We

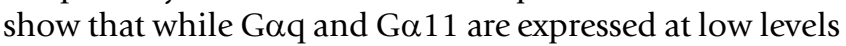
in taste buds, Go14 is expressed in a highly taste budselective manner. This observation is consistent with many previous reports of the ubiquitous distribution of Goq and G $\alpha 11$, while G $\alpha 14$ is restricted to a few highly specialized cell types[38]. Further, we show that Ga14 is limited to Type II taste cells, i.e. those that express taste GPCRs.

Mammalian taste buds use specialized taste GPCRs (including the T1R and T2R families) to detect bitter, umami and sweet tastants. Both families of taste receptors activate the downstream signalling elements, PLC $\beta 2$ and IP3R3[9,12,20,27,39]. The T2R receptors couple to Gagus $[22,40]$ but the Ga subunits activated in situ by the $\mathrm{T} 1 \mathrm{R}$ receptors are not yet defined. Whereas Gagus is substantially co-expressed with $\mathrm{T} 1 \mathrm{R}$ receptors in the anterior taste fields, such is not the case for posterior taste fields[24,25] where only a fraction of T1R3-expressing taste cells co-express Gagus. Hence, Gagus is unlikely to be the $\mathrm{G} \alpha$ subunit associated with the T1R receptors in the posterior tongue. We report here the obligatory co-expression of Ga14 with the sweet receptor T1R2+T1R3 in foliate and vallate taste fields. Accordingly, we suggest that sweet transduction in posterior, but not anterior gustatory fields involves G $\alpha 14$. Whether G $\alpha 14$ couples directly to the sweet taste receptor or to other GPCRs intimately associated with sweet detection remains to be determined.

The different taste receptors are not homogeneous across the taste fields of the tongue but show regional differences[25,41]. The T1R1+T1R3 umami receptor is much more prevalent in the anterior taste fields (fungiform and palate) than in the posterior lingual fields (foliate and vallate). In posterior lingual taste fields, T1R3 more commonly partners with T1R2 forming a sweet receptor. Our single cell RT-PCR data show that over 70\% (10/14) of the T1R3-expressing cells also express T1R2. With in situ 

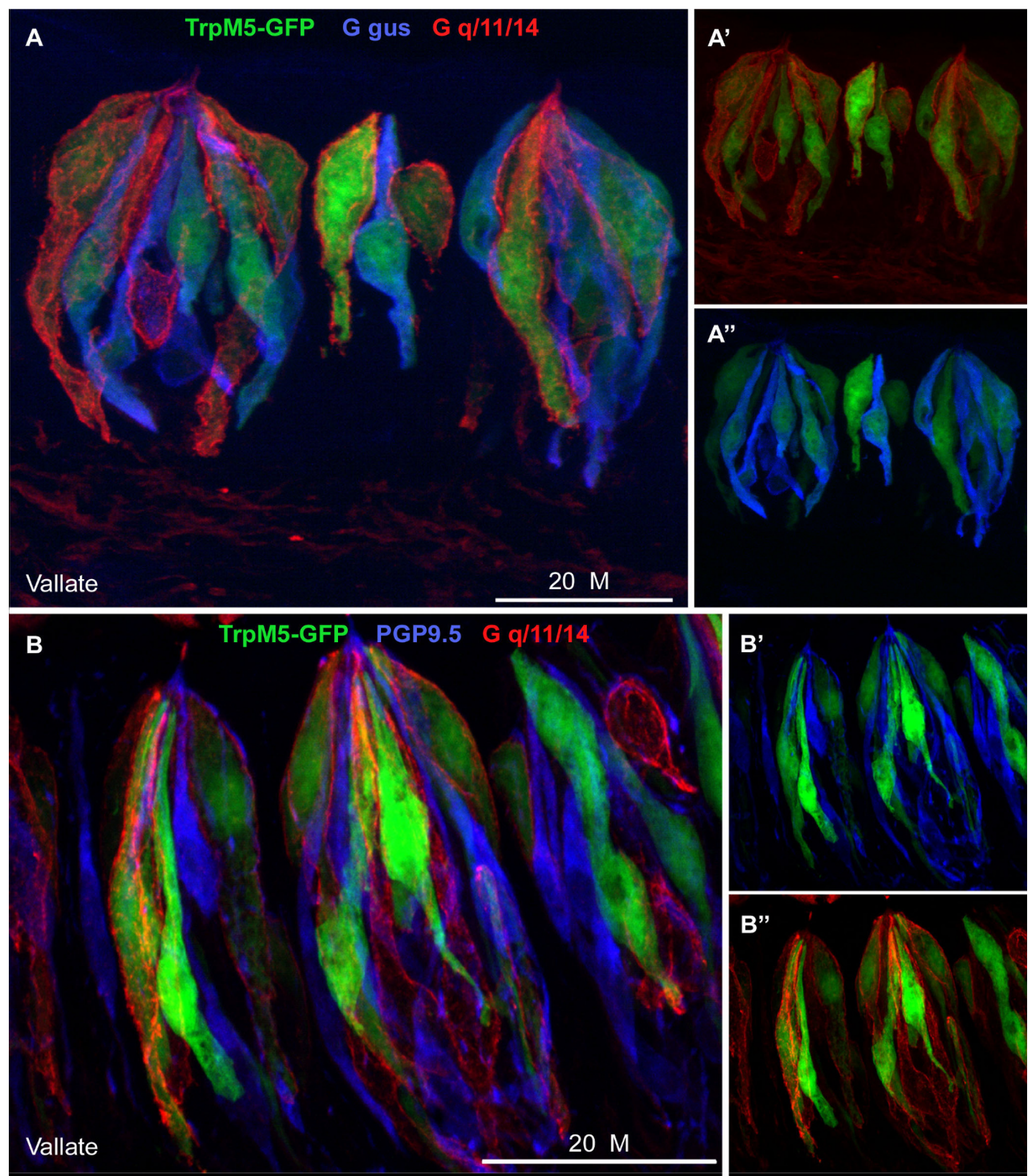

Figure 5

Gq/ I I/ / 4 immunoreactivity in Type II cells. (A) Co-localization of Gq// I//4 (red), Gagus (blue) in the vallate papilla of a TrpM5-GFP (green) animal. TrpM5 is a marker of Type II taste cells. Gq/I I/I4 stains about half (I4 of 27) of the TrpM5-GFP cells. Usually the Gaq-family immunoreactive cells are different from those positive for Gagus (blue). $A^{\prime}, A^{\prime \prime}$, represent single staining of TrpM5-GFP TBs used to obtain the merged pictures A. The figure in Additional file I shows single plane confocal images from this image set for comparison. (B) PGP9.5 (blue), a marker of Type III cells, does not co-localize with either Gq/ I I/I4 (red) or TrpM5 (green). The figure in Additional file 2 shows single plane confocal images from this image set for comparison. Scale bar $20 \mu \mathrm{M}$. 
Table I: TIR \& G-protein co-localization in Taste Buds

\begin{tabular}{|c|c|c|c|c|c|}
\hline \multirow[b]{2}{*}{ TrpM5 with } & \multicolumn{2}{|c|}{ Immunocytochem. } & \multirow[b]{2}{*}{ TrpM5 with } & \multicolumn{2}{|c|}{ Single Cell RT-PCR } \\
\hline & & $\%$ & & & $\%$ \\
\hline $\mathbf{G q} / \mathrm{I} / / \mathrm{I}$ & $14 / 27$ & 51.9 & $\mathbf{G} \alpha \mathbf{I}$ & $13 / 2 \mid$ & 61.9 \\
\hline Gagus & $17 / 27$ & 63.0 & Gagus & $|5 / 2|$ & 71.4 \\
\hline Gq/I I/I4+Gagus & $4 / 27$ & 14.8 & $\mathbf{G} \alpha \mathbf{l 4}+\mathbf{G} \alpha$ gus & $7 / 21$ & 33.3 \\
\hline \multirow[t]{4}{*}{ Gq/II/I4 with } & & & G $\alpha / 4$ with & & \\
\hline & $30 / 35$ & 85.7 & TIR3 & $13 / 14$ & 92.9 \\
\hline & & & TIR2 & $10 / 14$ & 71.4 \\
\hline & & & TIR3 + TIR2 & $10 / 14$ & 71.4 \\
\hline TIR3(GFP) & & & TIR3+TIR2 with & & \\
\hline (includes TIRI \& TTIR2) & & & $\mathbf{G} \alpha \mathbf{q}$ & $5 / 10$ & 50.0 \\
\hline$G q / I I / / 4$ & $30 / 41$ & 73.1 & $\mathbf{G} \alpha \mathbf{I 4}$ & $10 / 10$ & 100.0 \\
\hline Gagus & ||$/ 4 \mid$ & 26.8 & Gagus & $4 / 10$ & 40.0 \\
\hline
\end{tabular}

Results from immunocytochemistry are not significantly different $(p>0.05)$ from data from single cell RT-PCR (Fisher's Exact Test). The immunocytochemical data and RT-PCR data showing co-expression of gustducin with TIRs is not directly comparable since some cells express only TIR3 and not TIR2+TIR3
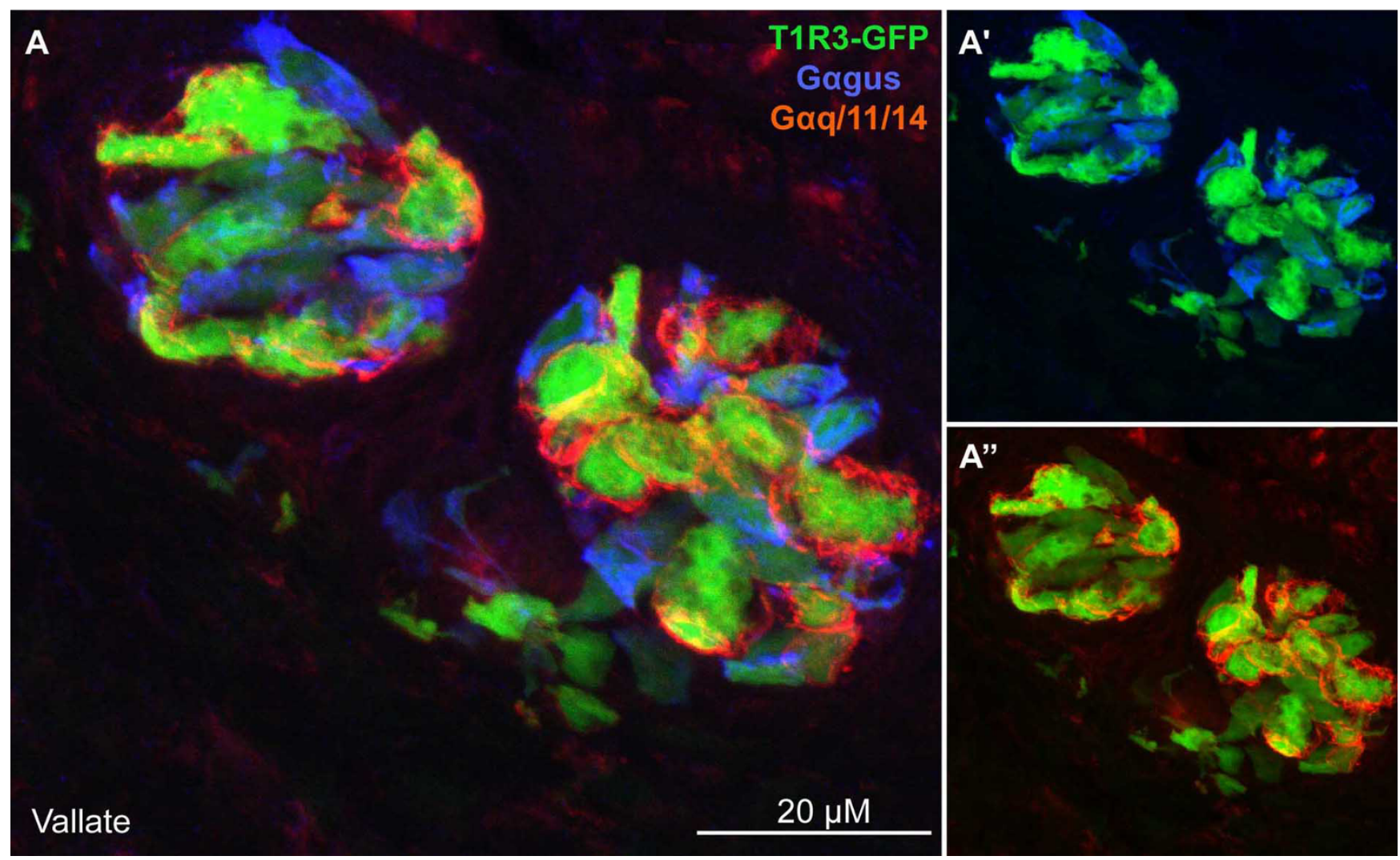

\section{Figure 6}

Gaq-family immunoreactivity co-localizes with TIR3-GFP. In vallate papilla TBs, the Gq/I I/I4 antibody (red) stains most of TIR3-GFP (green) cells (30 of 4I). Fewer cells are strongly positive for Gagus (blue). The large majority of Gq/I I/I4IR cells (30 of 35) exhibit TIR3-GFP. Only about half of GaGus IR cells show TIR3-GFP expression). The figure in Additional file 3 shows single plane confocal images from this image set for comparison. Scale bar $20 \mu M$. 


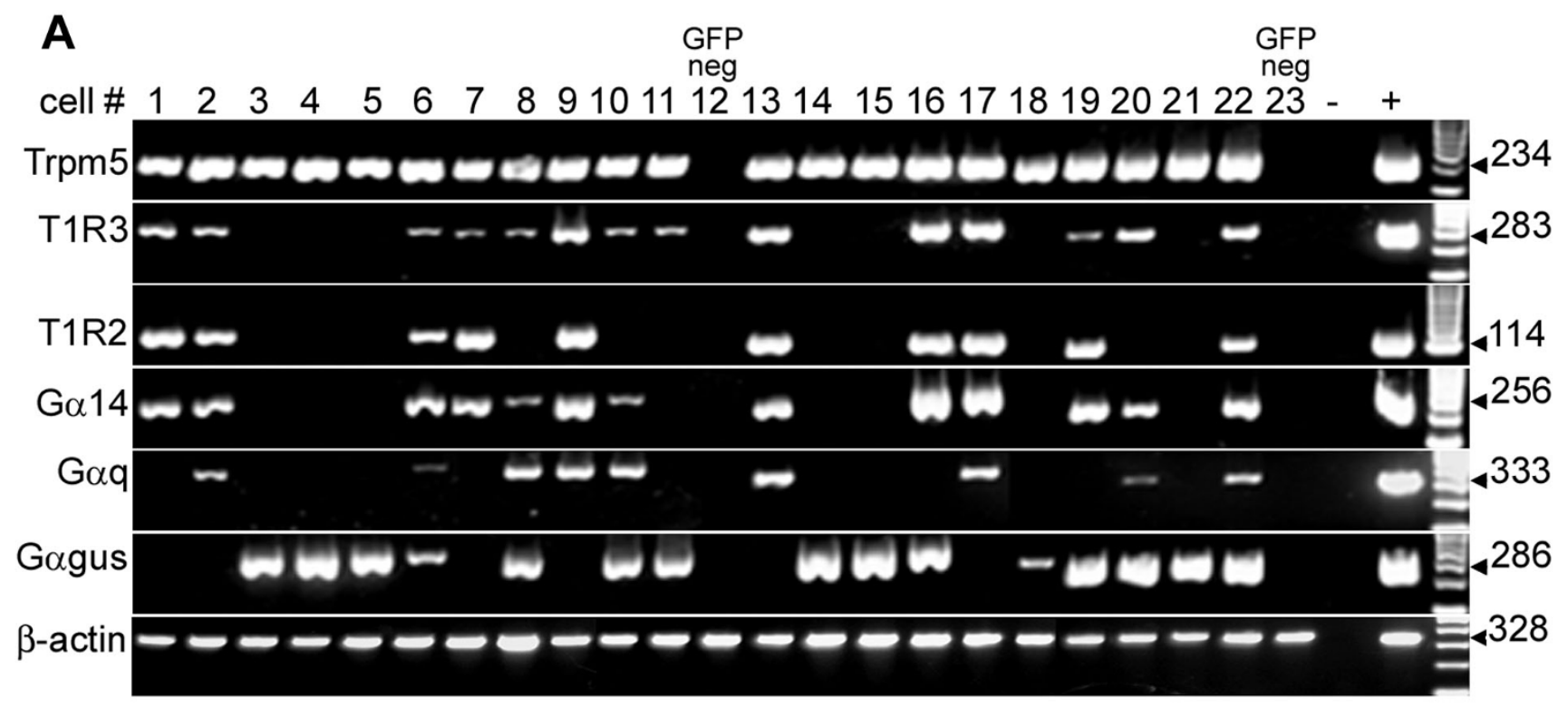

\section{B}

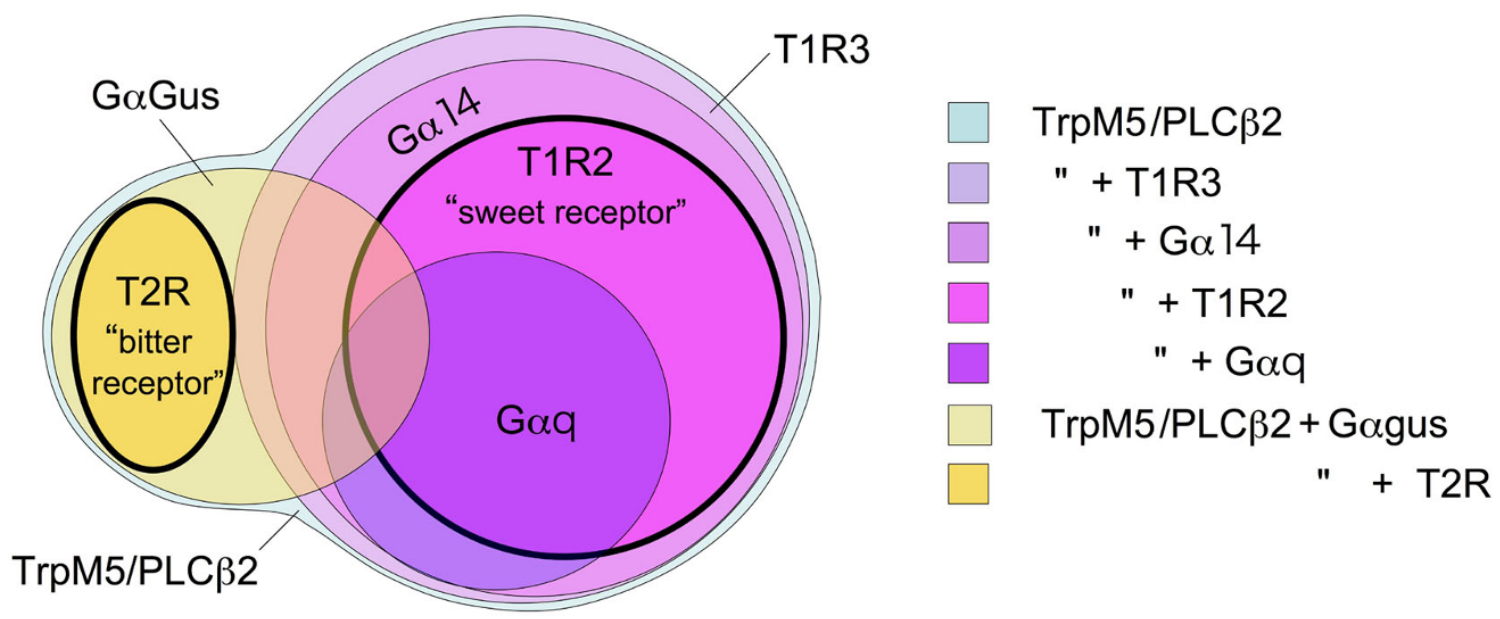

Figure 7

Single-cell expression profiling on Type II cells. A: mRNA was purified from 21 individual PLC $\beta 2-G F P$ cells and two GFP negative cells (\# I2 and \# 23) and reverse transcribed. Each cDNA was divided into 7 individual tubes and was used to assay

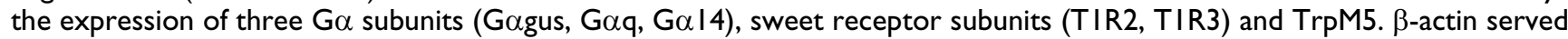
as a positive control for all samples. All PLC $\beta 2$-GFP positive cells displayed PCR product for TrpM5. In contrast, the G $\alpha$ subunits and sweet receptors were expressed in only a fraction of PLC $\beta 2-G F P$ cells. B. Venn diagram showing co-localization patterns based on the single cell RT-PCR analysis and previous studies on T2R localization patterns [I]. T2Rs do not co-localize with TIRs and in the vallate papilla, always co-localize with G $\alpha$ Gustducin. In our single cell RT-PCR study, all TIR2+TIR3 (sweet receptor) expressing taste cells express Gal4. A subset of these also express Gaq. The sweet receptive cells are themselves a subset of the Type II (receptor) taste cells identified by expression of PLC 32 and TrpM5. Another set of TrpM5/ PLC $\beta 2$-expressing cells express the T2R family of bitter receptors. These T2R-expressing cells invariably express G $\alpha$ Gustducin [I]. 
hybridization, two groups reported previously that $92 \%[25]$ and $98 \%[42]$ of the T1R3 expressing cells of the vallate papilla co-express T1R2. The lower percentage of co-localization we report may reflect differences in technique, given the higher sensitivity of single cell RT-PCR over in situ hybridization. Most of the T1R3-positive, non T1R2-expressing cells in our profiling displayed low levels of T1R3 (e.g. cells 8, 10, 11 of Fig. 6) and may not have been detected with in situ hybridization.

The T1R2+T1R3 heterodimer can functionally couple to a variety of Gai/o subunits in heterologous systems[19,43]. Since sweeteners activate adenylyl cyclase in vallate taste buds[44], Margolskee[45] has postulated that the T1R2+T1R3 receptor may couple to Gas. Indeed, Kusakabe et al[18] showed the expression of Gas, Gai2 and Gai3 in vallate taste buds, but not the tight association with sweet receptors. In contrast, our data show clearly that G 14 , a member of the Gaq family is consistently coexpressed with T1R2+T1R3 in posterior taste buds. Because sweet taste receptors are co-expressed with PLCB2[46], and mice in which PLC $\beta 2$ is knocked out show a severe deficit of sweet signaling[12], it is widely accepted that sweet transduction occurs via G $\beta \gamma$-mediated activation of PLC $\beta 2$. Yet PLC $\beta 2$ also can be activated robustly by members of the Gaq family[47]. Our study is the first demonstration of a consistent association of Ga14 (a Gaq family member) with taste receptors that activate PLC $\beta 2$.

The expression of Gagus in association with the sweet receptor in the palate and fungiform papilla is likely to account for the profound decrease of intake of sucrose and sweeteners in long-term taste behaviours in Gagus knockout mice[36,48,49]. On the basis of these previous results along with our current findings, Gagus knockout would be predicted to affect only the palatal and fungiform taste fields where Gagus is co-expressed with the sweet receptors. Transection of the gustatory nerves innervating only anterior taste fields results in near-total elimination of sweet taste preference in some behavioural assays despite the presence of an intact posterior lingual taste system[50]. Thus the loss of sweet-driven taste behaviours reported in Gagus knockouts is likely attributable to loss of function in the sweet-detecting taste buds of the anterior taste fields. Indeed more rigorous behavioural analysis of gustducin null mice reveals substantial residual sweet-guided taste behavior[49]. Electrophysiological analysis of taste nerves of Gagus-null mice reveals a profound loss of sweet-evoked activity in anterior tongue but only partial loss in posterior. This is consistent with our finding that relatively few sweet receptive taste cells also express Gagus. The degree of functional loss as measured by the magnitude of the glossopharyngeal nerve response in Gagus null mice, is, however, greater than would be predicted on the basis of the co-expression patterns[51]. Perhaps Gagus-expressing sweet-receptive cells disproportionately activate gustatory nerve fibers, or act synergistically with other cells within a taste bud to effect activation of the nerve fibers. Indeed, Roper[52] suggests the likelihood of intrabud intercellular communication playing an essential role in transmission of taste information.

\section{Conclusion}

The sweet-receptive taste cells of the posterior tongue express Ga14 while those in anterior taste buds express Gagus. These findings show that even within a single sensory system, the same receptor may couple with different G-protein alpha subunits in different functional parts of the system. Our results also account for the residual behavioural and neural activity to sweet tastants in Gagus-null animals.

\section{Methods \\ Animals}

All experiments were performed under protocols approved by the Animal Care and Use Committees of the CU Denver School of Medicine and the University of Miami School of Medicine. We used three strains of adult transgenic mice in which GFP is expressed from the promoters of T1R3, TRPM5, PLC $\beta 2$, or GAD1[31,34,53]. In taste buds from each of these strains, previous studies have shown that all cells expressing the relevant endogenous proteins also express GFP $[31,33,34]$. Gaq-deficient mice and littermate controls were obtained from Satya Kunapuli (Temple University, Philadelphia, PA) [54] with permission from Stefan Offermanns (University of Heidelberg, Heidelberg, Germany). This Gaq-null line was generated by replacement of sequence coding for amino acids 246-297 of Gaq by the neo gene and is described in detail in Cho et al[55]. The genotype of Gqnull mice was determined by PCR and was confirmed by platelet aggregation assay.

\section{Immunofluorescence}

We used a Gq-family antibody that is labelled and sold as anti-Gaq/11 (Santa Cruz Biotechnology; sc\# 392) although the manufacturer indicates that it likely will react with Ga14. The antigenic peptide, VFAAVKDTILQLNLKEYNLV, is located near the C-terminus, is $100 \%$ identical between Gaq and Ga11 and is $90 \%$ identical/100\% similar in Ga14 (all sequences from mouse). In contrast, Ga15 is only $45 \%$ identical/ $75 \%$ similar in this region. Thus, the antibody likely reacts with $\mathrm{G} \alpha \mathrm{q}$, Ga11 and Ga14, but not Ga15. To test the specificity of this broad Gaq family antibody, we also used an affinitypurified Ga11 specific antiserum (Santa Cruz Biotechnology; sc\# 394) directed against an N-terminal peptide (aa 13-29 from mouse sequence) that lacks any sequence 
similarity to either Gaq or Ga14. The cerebellum was used as a positive control tissue for these antisera since Purkinje cells express both Gaq and Ga11 but not Ga14 $[35,56]$.

Mice were perfusion-fixed in 4\% paraformaldehyde (PFA) in $0.1 \mathrm{M}$ phosphate buffer $(\mathrm{PB})$. Taste tissues (vallate, foliate and fungiform papillae and soft palate) were postfixed $\left(4^{\circ} \mathrm{C}, 60 \mathrm{~min}\right) ; 14 \mu \mathrm{m}$ cryosections were washed with phosphate-buffered saline (PBS), blocked with 1\% normal goat serum, and incubated with rabbit anti-Gaqfamily antibody (1:500); at $4^{\circ} \mathrm{C}$ overnight. The secondary antiserum used was Rhodamine RedTM-X-conjugated AffiniPure $^{\mathrm{TM}}$ Fab Fragment goat anti-Rabbit IgG $(\mathrm{H}+\mathrm{L})$ (1:100; Jackson ImmunoResearch Lab.; 111-297-003).

To examine co-expression of the Gaq family with other proteins in taste buds, and to avoid cross reactivity of multiple rabbit primary antibodies with a common secondary antibody, we used the Zenon Rabbit IgG Labeling Kit (Invitrogen, Z25308). For this, each primary antibody other than $\mathrm{G} \alpha \mathrm{q} / 11 / 14$ was pre-conjugated to Alexa Fluor 647 so that it did not require a secondary antibody for visualization. After the binding of the first primary and secondary antibodies was complete, the primary antibodyZenon 647 complex was applied to the slides for $80 \mathrm{~min}$ at $\mathrm{RT}$ in the dark, washed in PB with $0.2 \%$ Triton $\mathrm{X}-100$ and postfixed in PFA/PB. Slides were then coverslipped with Fluormount-G. Omission of primary antibodies (detected with Rhodamine Red-X or Zenon) resulted in no apparent fluorescent signal. The primary antibodies used as Zenon complexes were rabbit anti-PLC $\beta 2$ (1:200; Santa Cruz Biotechnology; sc\# 206); rabbit anti-Gagus (1:200: Santa Cruz Biotechnology; sc\# 395) and rabbit anti-PGP9.5 (Ubiquitin C-terminal hydrolase-L1; 1:200; AbD Serotec; 7863-0504).

All images were collected with an Olympus Fluoview confocal laser scanning microscope (LSCM) FV300 (Olympus Corporation). For each image, the channels were collected sequentially with single wavelength excitation and then merged to produce the composite image using the software Fluoview v5.0. This avoids the problem of bleedthrough of images resulting from side-band excitation of the fluorochromes. Brightness and contrast were adjusted in Adobe Photoshop 7.0. Images for Fig. 3 are displayed as negatives to permit visualization of faint fluorescent signal. This was accomplished by using the "Invert" command in Photoshop on the Red channel of the confocal image.

For quantification of immunocytochemical data, we counted immunoreactive cells from 3 sections through the vallate papilla from 2 different animals. An immunoreactive profile was included if it had an elongate mor- phology extending at least half the height of the taste bud and included an obvious nucleus. Cell fragments not including a nuclear profile were not included in the sample.

\section{$R T-P C R$ analysis}

Adult PLC $\beta 2$-GFP and GAD-GFP mice were killed by $\mathrm{CO}_{2}$ asphyxiation followed by decapitation, the tongue and palate were removed and a protease mixture consisting of $1 \mathrm{mg} / \mathrm{ml}$ collagenase, type A, $2.5 \mathrm{mg} / \mathrm{ml}$ dispase (both from Roche Products, Indianapolis, IN) and $1 \mathrm{mg} / \mathrm{ml}$ trypsin inhibitor (Sigma, St. Louis, MO) in Tyrode buffer was injected. Tyrode buffer consisted of, in mM: 139 $\mathrm{NaCl}, 5 \mathrm{KCl}, 2 \mathrm{CaCl}_{2}, 1 \mathrm{MgCl}_{2}, 10$ Hepes, 10 glucose, 10 $\mathrm{Na}$ pyruvate, and $5 \mathrm{NaHCO}_{3} ; \mathrm{pH} 7.2,318-323$ mOsm. Epithelium was peeled from underlying tissue after 20 min and incubated in $\mathrm{Ca} / \mathrm{Mg}$-free Tyrode's solution for 14 min. For Ca-Mg-free Tyrode buffer, $\mathrm{CaCl}_{2}$ and $\mathrm{MgCl}_{2}$ were replaced with 2 mM each EGTA and BAPTA.

To avoid contamination of samples with non-taste cells, taste buds from vallate, foliate, fungiform papillae and palate were collected in two stages. First, they were extracted under a stereomicroscope from the epithelium using glass pipettes (inner diameter at tip, $80 \mu \mathrm{m}$ ) and transferred into Tyrode buffer. Next, individual taste buds were identified by GFP fluorescence under under $200 \times$ magnification and transferred to lysis buffer (Absolutely Nanoprep kit, Stratagene). Total RNA was purified with DNAse I digestion and first strand CDNA synthesized with Superscript III (Invitrogen, Carlsbad, CA). PCR was performed in $20 \mu \mathrm{l}$ using cDNA of one taste bud as template per reaction. Positive and negative controls were run in parallel from master mixes. We designed PCR primers using published cDNA sequences for each gene. Because G $\alpha \mathrm{q}, \alpha 11$ and $\alpha 14$ are highly homologous, we placed primers in the most divergent regions. Primers are listed in Table 2. PCR was performed for 35 cycles. Most primer pairs spanned at least one intron to avoid amplifying genomic DNA. PCR products for all genes were validated by DNA sequencing.

\section{Single-cell RT-PCR}

Vallate taste buds were collected from PLC $\beta 2$-GFP mice (as above), then cells were dissociated by gentle trituration. GFP-labeled single cells were collected each into 60 $\mu \mathrm{l}$ of lysis buffer containing $200 \mathrm{ng}$ of poly-Inosinic acid as a carrier, processed for RNA purification and cDNA synthesis. For preliminary analyses of cell type specific expression (Fig. 2), we collected individual GFP-labeled vallate taste cells, pooled them in lysis buffer and isolated RNA and linear amplified it as previously described [29]. The aRNA (amplified RNA) was subjected to reverse transcription and $0.1 \%$ of the cDNA was used as template for RTPCR (40 cycles). For analyses of single cells, mRNA from 
Table 2: Primers for RT-PCR

\begin{tabular}{|c|c|c|c|c|c|c|}
\hline \multicolumn{2}{|c|}{ Protein \& Gene } & \multirow{2}{*}{$\begin{array}{l}\text { Accession \# } \\
\text { NM } 008137 \\
\end{array}$} & \multirow{2}{*}{$\begin{array}{l}\text { Forward Primer }\left(\mathbf{5}^{\prime} \rightarrow \mathbf{3}^{\prime}\right) \\
\text { attagctacttcccagagtacaca }\end{array}$} & \multirow{2}{*}{$\begin{array}{l}\text { Reverse Primer }\left(5^{\prime} \rightarrow 3^{\prime}\right) \\
\text { gctcagatcaccctctgtct }\end{array}$} & \multirow{2}{*}{$\begin{array}{c}\text { Product bp } \\
256\end{array}$} & \multirow{2}{*}{$\begin{array}{c}\text { Anneal }{ }^{\circ} \mathrm{C} \\
62^{\circ} \mathrm{C}\end{array}$} \\
\hline $\mathrm{G} \alpha 14$ & Gnal4 & & & & & \\
\hline & & & * tcatgcaacagagggacttg & * agggccatgctcaattacac & 294 & $60^{\circ} \mathrm{C}$ \\
\hline \multirow[t]{2}{*}{$\mathrm{G} \alpha q$} & Gnaq & NM 008139 & gtcgactacttcccagaatatgat & agtccaggacggcaataaat & 333 & $62^{\circ} \mathrm{C}$ \\
\hline & & & * aacacacaccatccgtcaga & * ggcaagcagtggtctctagc & 229 & $60^{\circ} \mathrm{C}$ \\
\hline Gall & Gnall & NM 010301 & agcccaagtcctgagtttga & tgccaagtcagagtggagaa & 236 & $60^{\circ} \mathrm{C}$ \\
\hline Gagus & Gnat3 & NM 001081143 & gcaaccacctccattgttct & agaagagcccacagtctttgag & 286 & $58^{\circ} \mathrm{C}$ \\
\hline PLC $\beta 2$ & Plcb2 & NM 177568 & gagcaaatcgccaagatgat & ccttgtctgtggtgaccttg & 163 & $60^{\circ} \mathrm{C}$ \\
\hline SNAP25 & Snap25 & NM 011428 & ggcaataatcaggatggagtag & agatttaaccacttcccagca & 310 & $58^{\circ} \mathrm{C}$ \\
\hline TIR2 & Tas/r2 & NM 031873 & aagcatcgectcctactcc & ggctggcaactcttagaacac & 114 & $58^{\circ} \mathrm{C}$ \\
\hline TIR3 & Tas $/ r 3$ & NM 031872 & gaagcatccagatgacttca & gggaacagaaggacactgag & 283 & $58^{\circ} \mathrm{C}$ \\
\hline TrpM5 & Trpm5 & NM 020277 & gtctggaatcacaggccaac & gttgatgtgccccaaaaact & 234 & $58^{\circ} \mathrm{C}$ \\
\hline$\beta$-actin & Actb & NM 007393 & ccctgtgctgctcacc & gcacgatttccctctcag & 328 & $58^{\circ} \mathrm{C}$ \\
\hline
\end{tabular}

Primers marked * $(\mathrm{G} \alpha \mid 4$ and $\mathrm{G} \alpha q)$ are located closer to the mRNA 3' end and were only used on amplified RNA from pools of GFP-expressing cells (Fig. 2).

each cell was reverse transcribed and then each $20 \mu \mathrm{l}$ single cell cDNA was divided as follows: $5 \%$ each for $\beta$-actin and TrpM5, 10\% each for Gagus and Ga14, 20\% each for T1R2 and T1R3 and 30\% for Gaq. PCR was performed in $20 \mu \mathrm{l}$ for 40 cycles.

\section{Quantitative RT-PCR}

Quantitative RT-PCR was carried out as previously described[57] using the same primers as for end point PCR, and SYBR Green PCR mix (Bio-Rad) in a Bio-Rad iQ iCycler. Three independent samples of CV taste buds and of adjacent non-taste epithelium were purified and analyzed in parallel. The concentration of each mRNA was compared to a standard curve generated from a sequencevalidated template and calculated using MyiQ software (Bio-Rad). All mRNA concentrations were normalized to $\beta$-actin mRNA which was run in parallel.

\section{Authors' contributions}

MT carried out immunocytochemistry, performed histological analysis and documentation and characterized the Ga14 antiserum. GD performed the molecular studies including RT-PCR, quantitative RT-PCR and single cell RTPCR-based profiling. MT and GD carried out the bulk of the experimental work for this project and contributed equally to the project. SK maintained and genotyped the Gaq-null mice, prepared tissue from Gaq-KO and paired WT animals for histological analysis. JB assisted with the immunocytochemical preparations and TEF assisted with documentation and analysis. NC and TEF supervised the molecular and histological studies respectively, and were instrumental in the conceptual design and analysis of the data. All authors contributed to writing and editing the manuscript.

\section{Additional material}

\section{Additional file 1}

Gq/11/14 and Gagus staining in vallate taste buds in a TrpM5-GFP mouse. Single confocal image planes from the image shown in Fig. 3A; TrpM5-GFP (B, green), Gagus (D, blue) and Gq/11/14 (F, red), respectively. Co-localization in single plane images of TrpM5-GFP and Gagus (A), TrpM5-GFP and Gq/11/14 (C), Gagus and Gq/11/14 (E) in the vallate papilla. Panel $G$ shows the the $z$-stack of the combined Gogus and $\mathrm{Gq} / 11 / 14$ images equivalent to text Fig. 3A. TrpM5 is a marker of Type II taste cells. Gq/11/14 stains about half (14 of 27) of the TrpM5-GFP cells. Usually the $\mathrm{Gq} / 11 / 14$ immunoreactive cells are different from those positive for Gagus. Scale bar $20 \mu \mathrm{M}$.

Click here for file

[http://www.biomedcentral.com/content/supplementary/14712202-9-110-S1.jpeg] 


\section{Additional file 2}

Gaq/11/14 and PGP9.5 staining in TrpM5-GFP mouse. Single confocal image planes from the image shown in Fig. 3B; TrpM5-GFP $(B$, green), Gq/11/14 (D, red) and PGP9.5 $(F$, blue $)$, respectively. Co-localization in single plane images of TrpM5-GFP and Gq/11/14 (A), TrpM5GFP and PGP9.5 (C), PGP9.5 and Gq/11/14 (E) in the vallate papilla. In $G$ the $z$-stack of the entire $E$ panel single plane images. PGP9.5, $a$ marker of Type III cells, does not co-localize with either $\mathrm{Gq} / 11 / 14$ or TrpM5. Scale bar $20 \mu \mathrm{M}$.

Click here for file

[http://www.biomedcentral.com/content/supplementary/14712202-9-110-S2.jpeg]

\section{Additional file 3}

Gq/11/14 and Gagus staining in T1R3-GFP mouse. Single confocal image planes from the image shown in Fig. 5; T1R3-GFP ( $B$, green $), G q /$ $11 / 14(D, r e d)$ and Gagus $(F$, blue $)$, respectively. Co-localization in single plane images of TrpM5-GFP and Gq/11/14 (A), TrpM5-GFP and Gagus (C), Gagus and Gq/11/14 (E) in the vallate papilla. The Gq/11/ 14 antibody stains most of T1R3-GFP cells (30 of 41). Fewer cells are strongly positive for Gagus (blue). The large majority of Gq/11/14-IR cells (30 of 35) exhibit T1R3-GFP. Only about half of Gagus IR cells show T1R3-GFP expression. Scale bar $20 \mu \mathrm{M}$.

Click here for file

[http://www.biomedcentral.com/content/supplementary/14712202-9-110-S3.jpeg]

\section{Acknowledgements}

The authors thank Robert Margolskee (Mt. Siani Medical Ctr.) and Sami Damak (Nestle Research Ctr.) for making the TrpM5-GFP and TIR3-GFP animals available for study. Similarly, the authors thank Satya Kunapuli (Temple Univ.) and Stefan Offermanns (Univ. Heidelberg) for facilitating and permitting use of the Gaq-KO mice.

This work was supported by NIH grants to T.E.F. (P30DC004657; DC007495), N.C. (DC00602I; DC006308).

Aspects of this work were presented at the International Symposium on Olfaction \& Taste, San Francisco, CA, July 2008 and published in abstract form in Chem Senses 2008, 38(4) SI 44. Since the initial submission and acceptance of this manuscript a related paper was published: Shindo $Y$, Miura H, Carninci P, Kawai J, Hayashizaki Y, Ninomiya Y, Hino A, Kanda T, Kusakabe $Y, G$ alpha 14 is a candidate mediator of sweet/umami signal transduction in the posterior region of the mouse tongue: Biochem Biophys Res Commun. 2008, Nov 21; 376(3): 504-8. Epub 2008 Sep 16.

\section{References}

I. Adler E, Hoon MA, Mueller KL, Chandrashekar J, Ryba NJ, Zuker CS: A novel family of mammalian taste receptors. Cell 2000 , I00(6):693-702.

2. Chandrashekar J, Mueller KL, Hoon MA, Adler E, Feng L, Guo W, Zuker CS, Ryba NJ: T2Rs function as bitter taste receptors. Cell 2000, I00(6):703-7II.

3. Matsunami H, Montmayeur JP, Buck LB: A family of candidate taste receptors in human and mouse. Nature 2000 404(6778):60I-604.

4. Chaudhari N, Landin AM, Roper SD: A metabotropic glutamate receptor variant functions as a taste receptor. Nat Neurosci 2000, 3(2): II3-119.
5. Li X, Staszewski L, Xu H, Durick K, Zoller M, Adler E: Human receptors for sweet and umami taste. Proc Natl Acad Sci USA 2002, 99(7):4692-4696.

6. Nelson G, Chandrashekar J, Hoon MA, Feng L, Zhao G, Ryba NJ, Zuker CS: An amino-acid taste receptor. Nature 2002, 416(6877): 199-202.

7. San Gabriel A, Uneyama H, Yoshie S, Torii K: Cloning and characterization of a novel mGluRI variant from vallate papillae that functions as a receptor for L-glutamate Stimuli. Chem Senses 2005, 30(Suppl I):i25-26.

8. Nelson G, Hoon MA, Chandrashekar J, Zhang Y, Ryba NJ, Zuker CS: Mammalian sweet taste receptors. Cell 200I, I 06(3):38I-390.

9. Huang L, Shanker YG, Dubauskaite J, Zheng JZ, Yan W, Rosenzweig $\mathrm{S}$, Spielman Al, Max M, Margolskee RF: Ggammal 3 colocalizes with gustducin in taste receptor cells and mediates IP3 responses to bitter denatonium. Nat Neurosci 1999, 2(12): 1055-1062.

10. Rossler P, Boekhoff I, Tareilus E, Beck S, Breer H, Freitag J: G protein betagamma complexes in circumvallate taste cells involved in bitter transduction. Chem Senses 2000, 25(4):4|3-42I.

II. Perez CA, Huang L, Rong M, Kozak JA, Preuss AK, Zhang H, Max M, Margolskee RF: A transient receptor potential channel expressed in taste receptor cells. Nat Neurosci 2002 5(II): $1169-1176$

12. Zhang Y, Hoon MA, Chandrashekar J, Mueller KL, Cook B, Wu D, Zuker CS, Ryba NJ: Coding of sweet, bitter, and umami tastes: different receptor cells sharing similar signaling pathways. Cell 2003, I I 2(3):293-30I.

13. Yan W, Sunavala G, Rosenzweig S, Dasso M, Brand JG, Spielman Al: Bitter taste transduced by PLC-beta(2)-dependent rise in IP(3) and alpha-gustducin-dependent fall in cyclic nucleotides. Am J Physiol Cell Physiol 200I, 280(4):C742-75I.

14. Caicedo $A$, Jafri MS, Roper SD: In situ $\mathrm{Ca2}+$ imaging reveals neurotransmitter receptors for glutamate in taste receptor cells. J Neurosci 2000, 20(2 I):7978-7985.

15. McLaughlin SK, McKinnon PJ, Margolskee RF: Gustducin is a tastecell-specific $G$ protein closely related to the transducins. Nature 1992, 357(6379):563-569.

16. McLaughlin SK, McKinnon PJ, Spickofsky N, Danho W, Margolskee RF: Molecular cloning of $\mathbf{G}$ proteins and phosphodiesterases from rat taste cells. Physiol Behav 1994, 56(6): I I57-I I 64.

17. Kusakabe Y, Yamaguchi E, Tanemura K, Kameyama K, Chiba N, Arai $S$, Emori $Y$, Abe K: Identification of two alpha-subunit species of GTP-binding proteins, Galpha 15 and Galphaq, expressed in rat taste buds. Biochim Biophys Acta 1998, 1403(3):265-272

18. Kusakabe Y, Yasuoka A, Asano-Miyoshi M, Iwabuchi K, Matsumoto I, Arai S, Emori Y, Abe K: Comprehensive study on $\mathbf{G}$ protein alpha-subunits in taste bud cells, with special reference to the occurrence of Galphai2 as a major Galpha species. Chem Senses 2000, 25(5):525-531.

19. Ozeck M, Brust P, Xu H, Servant G: Receptors for bitter, sweet and umami taste couple to inhibitory $G$ protein signaling pathways. Eur J Pharmacol 2004, 489(3): I39-149.

20. Asano-Miyoshi M, Abe K, Emori Y: Co-expression of calcium signaling components in vertebrate taste bud cells. Neurosci Lett 2000, 283(I):6I-64

21. Ming D, Ninomiya Y, Margolskee RF: Blocking taste receptor activation of gustducin inhibits gustatory responses to bitter compounds. Proc Natl Acad Sci USA 1999, 96( I7):9903-9908.

22. Caicedo A, Pereira E, Margolskee RF, Roper SD: Role of the G-protein subunit alpha-gustducin in taste cell responses to bitter stimuli. J Neurosci 2003, 23(30):9947-9952.

23. Wong GT, Gannon KS, Margolskee RF: Transduction of bitter and sweet taste by gustducin. Nature 1996, 38 I(6585):796-800

24. Stone LM, Barrows J, Finger TE, Kinnamon SC: Expression of TIRs and gustducin in palatal taste buds of mice. Chem Senses 2007, 32(3):255-262

25. Kim MR, Kusakabe $Y$, Miura $H$, Shindo $Y$, Ninomiya $Y$, Hino A: Regional expression patterns of taste receptors and gustducin in the mouse tongue. Biochem Biophys Res Commun 2003, 3 I 2(2):500-506.

26. Yee CL, Yang R, Bottger B, Finger TE, Kinnamon JC: "Type III" cells of rat taste buds: immunohistochemical and ultrastructural studies of neuron-specific enolase, protein gene product 9.5 , and serotonin. I Comp Neurol 200I, 440(I):97-I08. 
27. Miyoshi MA, Abe K, Emori Y: IP(3) receptor type 3 and PLCbeta2 are co-expressed with taste receptors TIR and T2R in rat taste bud cells. Chem Senses 200I, 26(3):259-265.

28. Clapp TR, Yang R, Stoick CL, Kinnamon SC, Kinnamon JC: Morphologic characterization of rat taste receptor cells that express components of the phospholipase $\mathbf{C}$ signaling pathway. Comp Neurol 2004, 468(3):3 | I-32I.

29. DeFazio RA, Dvoryanchikov G, Maruyama Y, Kim JW, Pereira E, Roper SD, Chaudhari N: Separate populations of receptor cells and presynaptic cells in mouse taste buds. J Neurosci 2006 , 26( I 5):3971-3980.

30. Medler KF, Margolskee RF, Kinnamon SC: Electrophysiological characterization of voltage-gated currents in defined taste cell types of mice. J Neurosci 2003, 23(7):2608-26I7.

3I. Clapp TR, Medler KF, Damak S, Margolskee RF, Kinnamon SC: Mouse taste cells with $G$ protein-coupled taste receptors lack voltage-gated calcium channels and SNAP-25. BMC Biol 2006, 4:7.

32. Strathmann $M$, Simon MI: G protein diversity: a distinct class of alpha subunits is present in vertebrates and invertebrates. Proc Natl Acad Sci USA 1990, 87(23):9II3-9I I7.

33. Tomchik SM, Berg S, Kim JW, Chaudhari N, Roper SD: Breadth of tuning and taste coding in mammalian taste buds. I Neurosci 2007, 27(40): 10840-10848.

34. Kim JW, Roberts C, Maruyama Y, Berg S, Roper S, Chaudhari N Faithful expression of GFP from the PLCbeta2 promoter in a functional class of taste receptor cells. Chem Senses 2006 , 3 I(3):2I3-2I9.

35. Hartmann J, Blum R, Kovalchuk Y, Adelsberger H, Kuner R, Durand GM, Miyata M, Kano M, Offermanns S, Konnerth A: Distinct roles of Galpha(q) and Galphal I for Purkinje cell signaling and motor behavior. J Neurosci 2004, 24(22):5। I9-5I30.

36. Ruiz-Avila L, McLaughlin SK, Wildman D, McKinnon PJ, Robichon A, Spickofsky N, Margolskee RF: Coupling of bitter receptor to phosphodiesterase through transducin in taste receptor cells. Nature 1995, 376(6535):80-85.

37. Ming D, Ruiz-Avila L, Margolskee RF: Characterization and solubilization of bitter-responsive receptors that couple to gustducin. Proc Natl Acad Sci USA 1998, 95( I 5):8933-8938.

38. Wilkie TM, Scherle PA, Strathmann MP, Slepak VZ, Simon MI: Characterization of $\mathbf{G}$-protein alpha subunits in the $\mathbf{G q}$ class: expression in murine tissues and in stromal and hematopoietic cell lines. Proc Natl Acad Sci USA 199I, 88(22): I0049-10053.

39. Clapp TR, Stone LM, Margolskee RF, Kinnamon SC: Immunocytochemical evidence for co-expression of Type III IP3 receptor with signaling components of bitter taste transduction. $B M C$ Neurosci 200I, 2(1):6.

40. Ueda T, Ugawa S, Yamamura H, Imaizumi Y, Shimada S: Functional interaction between $T 2 R$ taste receptors and G-protein alpha subunits expressed in taste receptor cells. J Neurosci 2003, 23( I 9):7376-7380.

41. Hoon MA, Adler E, Lindemeier J, Battey JF, Ryba NJ, Zuker CS: Putative mammalian taste receptors: a class of taste-specific GPCRs with distinct topographic selectivity. Cell 1999 , 96(4):54|-55|.

42. Montmayeur JP, Liberles SD, Matsunami H, Buck LB: A candidate taste receptor gene near a sweet taste locus. Nat Neurosci 200I, 4(5):492-498.

43. Sainz E, Cavenagh MM, Lopezjimenez ND, Gutierrez JC, Battey JF, Northup JK, Sullivan SL: The G-protein coupling properties of the human sweet and amino acid taste receptors. Dev Neurobiol 2007, 67(7):948-959.

44. Naim M, Ronen T, Striem BJ, Levinson M, Zehavi U: Adenylate cyclase responses to sucrose stimulation in membranes of pig circumvallate taste papillae. Comp Biochem Physiol B 1991, I 00(3):455-458.

45. Margolskee RF: Molecular mechanisms of bitter and sweet taste transduction. J Biol Chem 2002, 277(I): I-4.

46. Rossler P, Kroner C, Freitag J, Noe J, Breer H: Identification of a phospholipase $\mathbf{C}$ beta subtype in rat taste cells. Eur J Cell Biol 1998, 77(3):253-26|.

47. Lee SB, Shin SH, Hepler JR, Gilman AG, Rhee SG: Activation of phospholipase C-beta 2 mutants by $\mathbf{G}$ protein alpha $\mathrm{q}$ and beta gamma subunits. J Biol Chem 1993, 268(34):25952-25957.

48. Damak S, Rong M, Yasumatsu K, Kokrashvili Z, Perez CA, Shigemura N, Yoshida R, Mosinger B Jr, Glendinning JI, Ninomiya Y, et al.:
Trpm5 null mice respond to bitter, sweet, and umami compounds. Chem Senses 2006, 3 I (3):253-264.

49. Glendinning JI, Bloom LD, Onishi M, Zheng KH, Damak S, Margolskee RF, Spector AC: Contribution of alpha-gustducin to tasteguided licking responses of mice. Chem Senses 2005, 30(4):299-316.

50. Krimm RF, Nejad MS, Smith JC, Miller IJ Jr, Beidler LM: The effect of bilateral sectioning of the chorda tympani and the greater superficial petrosal nerves on the sweet taste in the rat. Physiol Behav 1987, 4I(5):495-50I.

5I. Danilova V, Damak S, Margolskee RF, Hellekant G: Taste responses to sweet stimuli in alpha-gustducin knockout and wild-type mice. Chem Senses 2006, 3 I (6):573-580.

52. Roper SD: Signal transduction and information processing in mammalian taste buds. Pflugers Arch 2007, 454(5):759-776.

53. Damak S, Rong M, Yasumatsu K, Kokrashvili Z, Varadarajan V, Zou S, Jiang P, Ninomiya Y, Margolskee RF: Detection of sweet and umami taste in the absence of taste receptor TIr3. Science 2003, 30 I (5634):850-853.

54. Kim S, Jin J, Kunapuli SP: Akt activation in platelets depends on Gi signaling pathways. J Biol Chem 2004, 279(6):4I86-4I 95.

55. Cho MJ, Liu J, Pestina TI, Steward SA, Thomas DW, Coffman TM, Wang $D$, Jackson CW, Gartner TK: The roles of alpha Ilb beta 3 . mediated outside-in signal transduction, thromboxane A2, and adenosine diphosphate in collagen-induced platelet aggregation. Blood 2003, I 0 I(7):2646-265 I.

56. Tanaka J, Nakagawa S, Kushiya E, Yamasaki M, Fukaya M, Iwanaga T, Simon MI, Sakimura K, Kano M, Watanabe M: Gq protein alpha subunits Galphaq and Galpha I I are localized at postsynaptic extra-junctional membrane of cerebellar Purkinje cells and hippocampal pyramidal cells. Eur I Neurosci 2000, I 2(3):78I-792

57. Dvoryanchikov G, Tomchik SM, Chaudhari N: Biogenic amine synthesis and uptake in rodent taste buds. I Comp Neurol 2007 505(3):302-313.
Publish with Biomed Central and every scientist can read your work free of charge

"BioMed Central will be the most significant development for disseminating the results of biomedical research in our lifetime. "

Sir Paul Nurse, Cancer Research UK

Your research papers will be:

- available free of charge to the entire biomedical community

- peer reviewed and published immediately upon acceptance

- cited in PubMed and archived on PubMed Central

- yours - you keep the copyright
BiolMedcentral 